\title{
PEMANFAATAN TANAMAN AIR UNTUK MENURUNKAN KADAR BOD dan COD DALAM LIMBAH CAIR RUMAH POTONG HEWAN
}

\author{
Iqbal Abdi G, Ferry Kriswandana, Darjati \\ Kementerian Kesehatan RI \\ Politeknik Kesehatan Kemenkes Surabaya \\ Program Studi D-IV Kesehatan Lingkungan \\ Email: iqbalabdi6@gmail.com
}

\begin{abstract}
ABSTRAK
Kegiatan pemotongan hewan di rumah potong hewan sangat padat, sehingga berdampak pada banyaknya limbah cair yang dihasilkan dari kegiatan tersebut. Maka dibutuhkan sistem pengolahan limbah yang baik dan benar agar lingkungan tetap terjaga. Tujuan dari penelitian ini untuk mengetahui tanaman air jenis Pistia stratiotes dapat menurunkan kadar BOD dan COD sebagai pengolahan lanjut pada limbah cair rumah potong hewan.

Penelitian ini merupakan penelitian eksperimental dengan rancangan one group pretest-posttest design dan dianalisis secara analitik menggunakan uji One Way Anova. Hasil pemeriksaan rata-rata sesudah perlakuan kadar BOD dengan perlakuan 15 tanaman, 20 tanaman, 25 tanaman, dan 30 tanaman secara berurutan sebesar 226,45 ppm, 172,44 ppm, 120,52 ppm, dan 64,13 ppm, kadar COD secara berurutan sebesar 444,67 ppm, 346,80 ppm, 211,24 ppm, dan 109,38 ppm. Penurunan terbesar terjadi pada perlakuan 30 tanaman masing-masing per 50 liter air limbah yaitu BOD sebesar 83\%, COD sebesar 85,53\%. Uji One Way ANOVA menunjukkan hasil $p<0,05$ sehingga terdapat perbedaan signifikan.

Penelitian ini menunjukkan bahwa fitoremediasi menggunakan tanaman air Pistia stratiotes mampu menurunkan kadar BOD dan COD dalam air limbah rumah potong hewan.

Kata kunci: BOD, COD, Fitoremediasi, Tanaman Kayu apu (Pistia srtatiotes)

\section{ABSTRACT}

The slaughterhouse activities at abattoirs are very dense, which has an impact on the amount of liquid waste generated from these activities. Then it takes a good and correct waste treatment system so that the environment is maintained. The purpose of this study was to determine the Pistia stratiotes water plants can reduce levels of BOD and COD as further processing in slaughterhouse wastewater.

This study was an experimental study with one group pretest-posttest design and analyzed analytically using One Way Anova test. The average examination results after BOD treatment with 15 plants, 20 plants, 25 plants, and 30 plants each per 50 liters of wastewater in a sequence of $226.45 \mathrm{ppm}, 172.44 \mathrm{ppm}, 120.52 \mathrm{ppm}$, and $64.13 \mathrm{ppm}, \mathrm{COD}$ levels sequentially were $444.67 \mathrm{ppm}, 346.80 \mathrm{ppm}, 211.24$ $\mathrm{ppm}$, and $109.38 \mathrm{ppm}$. The biggest decrease occurred in the treatment of 30 plants, namely BOD of $83 \%$, COD of $85.53 \%$. One Way ANOVA test shows the results of $p$ $<0.05$ so that there are significant differences.
\end{abstract}


This study shows that phytoremediation using Pistia stratiotes water plants can reduce levels of $B O D$ and $C O D$ in abattoir wastewater.

Keywords: BOD, COD, Phytoremediation, Kayu Apu Aquatic Plant (Pistia statiotes)

\section{PENDAHULUAN}

Akhir-akhir ini semakin banyak Kegiatan Rumah Potong Hewan terjadi peningkatan jumlah limbah yang dihasilkan dari kegiatan pemotongan $(\mathrm{RPH})$ zat yang dapat menyebabkan pencemaran air adalah sisa buangan hewan di rumah potong hewan. yang mengandung zat pencemar yang Kegiatan tersebut seharusnya sudah sebagian besar berasal dari rumen. Zat melalui pengolahan air limbah, tetapi tersebut mengandung pencemar yang dalam pengolahan tersebut masih dapat membahayakan organisme di melebihi ambang batas. Hal tersebut perairan karena mengandung Biological dibuktikan pada hasil laboratorium yang mengalami peningkatan untuk Oxygen Demand (BOD) adalah jumlah pemeriksaan bulan Maret 2017 kadar BOD sebesar 104,36 ppm dan COD sebesar 181, 38 ppm, sedangkan bulan April 2017 kadar BOD sebesar 178,38 ppm dan COD sebesar 214,54 ppm.

Limbah RPH sebagian besar oksigen yang diperlukan oleh populasi mikroorganisme yang berada dalam kondisi aerob untuk menstabilkan materi organik (Qasyim,1985) dan Chemical Oxygen Demand (COD) adalah jumlah oksigen yang dibutuhkan untuk mengoksidasi materi organik yang berupa limbah organik yang dibutuhkan untuk mengoksidasi materi mengandung protein, lemak, dan organic dengan oksidasi secara karbohidrat yang cukup tinggi sehingga berpotensi sebagai pencemar lingkungan kimia(Qasyim,1985). Jika limbah cair tersebut tidak dilakukan pengolahan (Manendar 2010). Limbah yang sebelum dibuang ke badan air, dampak pengolahannya kurang baik dapat yang ditimbulkan akan sangat besar bagi memberikan dampak negatif terhadap lingkungan sekitar. Oleh karena itu, lingkungan. Upaya pengolahan limbah sesuai dengan Peraturan Gubernur Jawa cair yang baik dan optimal sebelum Timur Nomor 72 Tahun 2013 Tentang dibuang ke badan air sangat diperlukan. Baku Mutu Air Limbah Bagi Industri dan/atau Kegiatan Usaha Lainnya 
bahwa Baku Mutu Air Limbah Rumah

Penggunaan tanaman air Kayu

Potong Hewan kandungan BOD apu (Pistia stratiotes) untuk menurunkan maksimum $100 \mathrm{mg} / \mathrm{l}, \mathrm{COD}$ maksimum konsentrasi BOD dan COD dalam limbah 200 mg/l. Maka perlu adanya upaya cair telah dibuktikan melalui penelitian pengendalian untuk mendapatkan ilmiah yang dilakukan oleh Dhea berbagai alternatif pengolahan air limbah Ghiovani Raissa dan Bieby Voijant yang efektif dan efisien bagi setiap Tangahu yang berjudul Fitoremediasi Air kegiatan agar memenuhi standar. Hasil yang Tercemar Limbah Laundry dengan uji pendahuluan di Rumah Potong Menggunakan Kayu apu (Pistia Hewan (RPH) "X" yang menggunakan stratiotes). Hal ini menjadi dasar peneliti data sekunder hasil uji laboratorium untuk menggunakan tanaman air Kayu bulan April 2017 didapat hasil BOD 5 apu (Pistia stratiotes) untuk menurunkan sebesar 178,38 mg/L dan COD sebesar konsentrasi BOD dan COD limbah cair $214,54 \mathrm{mg} / \mathrm{L}$. Dari data tersebut dapat yang dihasilkan oleh rumah potong disimpulkan bahwa untuk BOD dan COD hewan (RPH).

dirumah potong hewan " $X$ " belum memenuhi standard.

\section{METODE PENELITIAN}

Jenis penelitian yang dilakukan adalah penelitian pra eksperimen dan menggunakan rancangan "One Group Pre-Post Test Design". Obyek penelitian ini adalah efektifitas tanaman air jenis Kayu Apu (Pistia stratiotes) dalam menurunkan kadar BOD dan COD dalam air limbah rumah potong hewan. Sampel dalam penelitian ini adalah outlet limbah cair dari rumah potong hewan. Teknik sampling yang digunakan adalah purposive sampling.

Analisis data yang digunakan yaitu analisis statistik dan deskriptif. Dalam analisis analitik ini peneliti menggunakan uji statistik Anova satu arah. Uji statistik tersebut bertujuan untuk mengetahui adanya perbedaan penurunan kadar BOD dan COD pada limbah Rumah Potong Hewan dari empat perlakuan yang -dilakukan. 


\section{HASIL PENELITIAN}

1. Hasil perlakuan reaktor percobaan dengan tanaman dan tanpa tanaman air jenis Pistia stratiotes

Tabel 1

KADAR BOD dan COD SEBELUM dan SESUDAH PERLAKUAN BERDASARKAN VARIASI TANAMAN

\begin{tabular}{|c|c|c|c|c|c|}
\hline \multirow[b]{2}{*}{ Replikasi } & \multirow[b]{2}{*}{$\begin{array}{c}\text { Variasi } \\
\text { Tanaman } \\
\text { (biji) }\end{array}$} & \multicolumn{2}{|c|}{ Sebelum } & \multicolumn{2}{|c|}{ Sesudah } \\
\hline & & $\begin{array}{c}\text { Kadar } \\
\text { BOD } \\
\text { (ppm) }\end{array}$ & $\begin{array}{c}\text { Kadar } \\
\text { COD } \\
(\mathbf{p p m})\end{array}$ & $\begin{array}{c}\text { Kadar } \\
\text { BOD } \\
(\text { ppm })\end{array}$ & $\begin{array}{l}\text { Kadar } \\
\text { COD } \\
\text { (ppm) }\end{array}$ \\
\hline 1 & \multirow{7}{*}{$\begin{array}{c}15 \mathrm{Biji} / 50 \\
\text { liter air } \\
\text { limbah }\end{array}$} & \multirow{7}{*}{377,60} & \multirow{7}{*}{765,10} & 230,60 & 454,85 \\
\hline 2 & & & & 219,83 & 435,60 \\
\hline 3 & & & & 224,52 & 441,68 \\
\hline 4 & & & & 230,80 & 452,70 \\
\hline 5 & & & & 226,51 & 438,50 \\
\hline Rata-rata & & & & 226,45 & 444,67 \\
\hline Kontrol & & & & 377,60 & 765,10 \\
\hline
\end{tabular}

2. Hasil perlakuan reactor percobaan dengan tanaman dan tanpa tanaman air jenis Pistia stratiotes

\section{Tabel 2}

KADAR BOD dan COD SEBELUM dan SESUDAH PERLAKUAN

BERDASARKAN VARIASI TANAMAN

\begin{tabular}{|c|c|c|c|c|c|}
\hline \multirow[b]{2}{*}{ Replikasi } & \multirow[b]{2}{*}{$\begin{array}{c}\text { Variasi } \\
\text { Tanaman } \\
\text { (biji) }\end{array}$} & \multicolumn{2}{|c|}{ Sebelum } & \multicolumn{2}{|c|}{ Sesudah } \\
\hline & & $\begin{array}{c}\text { Kadar BOD } \\
\text { (ppm) }\end{array}$ & $\begin{array}{l}\text { Kadar } \\
\text { COD } \\
(\mathrm{ppm})\end{array}$ & $\begin{array}{l}\text { Kadar BOD } \\
(\text { ppm) }\end{array}$ & $\begin{array}{c}\text { Kadar COD } \\
(\mathrm{ppm})\end{array}$ \\
\hline 1 & \multirow{7}{*}{$\begin{array}{c}20 \\
\text { Biji/50 } \\
\text { liter air } \\
\text { limbah }\end{array}$} & \multirow{7}{*}{382,50} & \multirow{7}{*}{760,51} & 180,80 & 359,65 \\
\hline 2 & & & & 168,50 & 345,25 \\
\hline 3 & & & & 172,60 & 350,20 \\
\hline 4 & & & & 170,56 & 338,10 \\
\hline 5 & & & & 169,75 & 340,82 \\
\hline $\begin{array}{c}\text { Rata- } \\
\text { rata }\end{array}$ & & & & 172,44 & 346,80 \\
\hline Kontrol & & & & 382,50 & 760,51 \\
\hline
\end{tabular}




\section{Hasil perlakuan reaktor percobaan dengan tanaman dan tanpa tanaman air jenis Pistia stratiotes}

Tabel 3

KADAR BOD dan COD SEBELUM dan SESUDAH PERLAKUAN

BERDASARKAN VARIASI TANAMAN

\begin{tabular}{|c|c|c|c|c|c|}
\hline \multirow[b]{2}{*}{ Replikasi } & \multirow{2}{*}{$\begin{array}{c}\text { Variasi } \\
\text { Tanaman } \\
\text { (biji) }\end{array}$} & \multicolumn{2}{|c|}{ Sebelum } & \multicolumn{2}{|c|}{ Sesudah } \\
\hline & & $\begin{array}{c}\text { Kadar BOD } \\
\text { (ppm) }\end{array}$ & $\begin{array}{c}\text { Kadar COD } \\
\text { (ppm) }\end{array}$ & $\begin{array}{c}\text { Kadar BOD } \\
\text { (ppm) }\end{array}$ & $\begin{array}{c}\text { Kadar COD } \\
\text { (ppm) }\end{array}$ \\
\hline 1 & \multirow{7}{*}{$\begin{array}{c}25 \\
\text { Biji/50 } \\
\text { liter air } \\
\text { limbah }\end{array}$} & \multirow{6}{*}{396,20} & \multirow{6}{*}{762,55} & 124,56 & 213,84 \\
\hline 2 & & & & 118,50 & 204,25 \\
\hline 3 & & & & 121,80 & 210,50 \\
\hline 4 & & & & 120,85 & 209,52 \\
\hline 5 & & & & 116,90 & 218,10 \\
\hline $\begin{array}{l}\text { Rata- } \\
\text { rata }\end{array}$ & & & & 120,52 & 211,24 \\
\hline Kontrol & & & & 396,20 & 762,55 \\
\hline
\end{tabular}

4. Hasil perlakuan reaktor percobaan dengan tanaman dan tanpa tanaman air jenis Pistia stratiotes

Tabel 4

KADAR BOD dan COD SEBELUM dan SESUDAH PERLAKUAN BERDASARKAN VARIASI TANAMAN

\begin{tabular}{|c|c|c|c|c|c|}
\hline \multirow[b]{2}{*}{ Replikasi } & \multirow[b]{2}{*}{$\begin{array}{c}\text { Variasi } \\
\text { Tanaman } \\
\text { (biji) }\end{array}$} & \multicolumn{2}{|c|}{ Sebelum } & \multicolumn{2}{|c|}{ Sesudah } \\
\hline & & $\begin{array}{c}\text { Kadar BOD } \\
\text { (ppm) }\end{array}$ & $\begin{array}{l}\text { Kadar } \\
\text { COD } \\
(\mathrm{ppm})\end{array}$ & $\begin{array}{l}\text { Kadar } \\
\text { BOD } \\
(\mathrm{ppm})\end{array}$ & $\begin{array}{l}\text { Kadar } \\
\text { COD } \\
(\mathrm{ppm})\end{array}$ \\
\hline 1 & \multirow{7}{*}{$\begin{array}{c}30 \mathrm{Biji} / 50 \\
\text { liter air } \\
\text { limbah }\end{array}$} & \multirow{6}{*}{376,90} & \multirow{6}{*}{755,80} & 68,50 & 123,85 \\
\hline 2 & & & & 65,82 & 115,10 \\
\hline 3 & & & & 66,75 & 108,26 \\
\hline 4 & & & & 60,70 & 98,10 \\
\hline 5 & & & & 58,90 & 101,60 \\
\hline Rata-rata & & & & 64,13 & 109,38 \\
\hline Kontrol & & & & 376,90 & 755,80 \\
\hline
\end{tabular}

5. Hasil Uji statistik kadar BOD

Tabel 5

HASIL UJI NORMALITAS KADAR BOD DALAM LIMBAH CAIR

\begin{tabular}{|c|c|c|c|c|c|c|c|}
\hline & \multirow[t]{2}{*}{ Perlakuan } & \multicolumn{3}{|c|}{$\begin{array}{l}\text { Tests of Normality } \\
\text { Kolmogorov-Smirnov }^{a}\end{array}$} & \multicolumn{3}{|c|}{ Shapiro-Wilk } \\
\hline & & Statistic & $\mathrm{df}$ & Sig. & Statistic & $\mathrm{df}$ & Sig. \\
\hline \multirow[t]{5}{*}{ Kadar_BOD } & Kontrol & .286 & 4 & . & .824 & 4 & .153 \\
\hline & 15 Tanaman & .218 & 5 & $.200^{*}$ & .917 & 5 & .508 \\
\hline & 20 Tanaman & .287 & 5 & $.200^{*}$ & .816 & 5 & .110 \\
\hline & 25 Tanaman & .152 & 5 & $.200^{*}$ & .983 & 5 & .951 \\
\hline & 30 Tanaman & .259 & 5 & $.200^{*}$ & .905 & 5 & .438 \\
\hline
\end{tabular}

*. This is a lower bound of the true significance.

a. Lilliefors Significance Correction 
Tabel 6

HASIL UJI ANOVA KADAR BOD DALAM LIMBAH CAIR

\begin{tabular}{lrrrrr} 
Kadar_BOD & $\begin{array}{c}\text { ANOVA } \\
\text { Sum of } \\
\text { Squares }\end{array}$ & df & $\begin{array}{c}\text { Mean } \\
\text { Square }\end{array}$ & F & Sig. \\
\hline Between Groups & 260496.435 & 4 & 65124.109 & 2363.19 & .000 \\
\hline Within Groups & 523.596 & 19 & 27.558 & & \\
\hline Total & 261020.031 & 23 & & & \\
\hline
\end{tabular}

Tabel V.7

HASIL UJI NORMALITAS KADAR COD DALAM LIMBAH CAIR

\begin{tabular}{llrrrrrr} 
& \multicolumn{4}{c}{ Tests of Normality } \\
& Perlakuan & \multicolumn{4}{c}{ Kolmogorov-Smirnov } & \multicolumn{3}{c}{ Shapiro-Wilk } \\
& & Statistic & Df & Sig. & Statistic & df & Sig. \\
\hline Kadar_COD & Kontrol & .201 & 4 & & .974 & 4 & .869 \\
\cline { 2 - 8 } & 15 Tanaman & .235 & 5 & .200 & .885 & 5 & .332 \\
\cline { 2 - 8 } & 20 Tanaman & .172 & 5 & .200 & .947 & 5 & .715 \\
\cline { 2 - 8 } & 25 Tanaman & .169 & 5 & .200 & .989 & 5 & .976 \\
\cline { 2 - 8 } & 30 Tanaman & .173 & 5 & .200 & .963 & 5 & .827 \\
\hline
\end{tabular}

*. This is a lower bound of the true significance.

a. Lilliefors Significance Correction

Tabel V.8

HASIL UJI ANOVA KADAR COD DALAM LIMBAH CAIR

\begin{tabular}{|c|c|c|c|c|c|}
\hline \multirow{2}{*}{ Kadar_COD } & \multicolumn{4}{|c|}{ ANOVA } & \multirow[b]{2}{*}{ Sig. } \\
\hline & $\begin{array}{l}\text { Sum of } \\
\text { Squares }\end{array}$ & df & $\begin{array}{l}\text { Mean } \\
\text { Square }\end{array}$ & $\mathrm{F}$ & \\
\hline Between Groups & 1104523.155 & 4 & 276130.789 & $\begin{array}{r}4477.59 \\
0\end{array}$ & .000 \\
\hline Within Groups & 1171.721 & 19 & 61.670 & & \\
\hline Total & 1105694.876 & 23 & & & \\
\hline
\end{tabular}

\section{PEMBAHASAN}

\section{Hasil Pengukuran Kadar BOD} dan COD Sesudah Perlakuan

Air limbah rumah potong hewan yang digunakan adalah air limbah yang memiliki kadar BOD dan COD melebihi baku mutu menurut Peraturan Gubernur Pengolahan limbah rumah potong hewan ini menggunakan sistem fitoremediasi dengan memanfaatkan tanaman air Pistia stratiotes sebaga tanaman penyerap zat pencemar sekitar.

Berdasarkan tabel V.1 Hasil Jawa Timur Nomor 72 Tahun 2013. analisis kadar BOD dan COD limbah cair 
rumah potong hewan pada reaktor A (15 tanaman) menunjukkan bahwa terjadi penurunan kadar BOD sebesar 226,45 sedangkan COD sebesar 444,67. Pada reaktor ini terdapat 15 tanaman air, sehingga penurunan kadar BOD dan COD belum maksimal.

Berdasarkan tabel V.2 Hasil analisis kadar BOD dan COD limbah cair rumah potong hewan pada reaktor B (20 tanaman) menunjukkan bahwa terjadi penurunan kadar BOD sebesar 172,44 dan COD sebesar 346,80 . Pada reactor ini terdapat 20 tanaman air, sehingga penurunan kadar BOD dan COD sudah lebih baik karena kepadatan tanaman meningkat, tetapi masih belum memenuhi baku mutu.

Berdasarkan tabel V.3 Hasil analisis kadar BOD dan COD limbah cair rumah potong hewan pada reaktor C (25 tanaman) menunjukkan bahwa terjadi penurunan kadar BOD sebesar 120,52 dan COD sebesar 211,24. Pada reactor ini terdapat 25 tanaman air, kepadatan tanaman meningkat, dan pemilihan tanaman lebih selektif lagi terutama bagian akar agar.

Berdasarkan tabel V.4 Hasil analisis kadar BOD dan COD limbah cair rumah potong hewan pada reaktor $\mathrm{D}$ (30 tanaman) menunjukkan bahwa terjadi penurunan kadar BOD sebesar 64,13dan COD sebesar 109,38. Pada reactor ini terdapat 30 tanaman air, penurunan kadar BOD dan COD mampu memenuhi syarat baku mutu. Hal ini didukung karena kepadatan tanaman yang meningkat dan pemilihan tanaman yang tepat untuk proses fitoremediasi.

Perbedaan penurunan antara reaktor $A, B, C$, dan $D$ bervariasi. Hal ini disebabkan karena jumlah tanaman yang sangat berpengaruh, sehingga didapat pada reactor $D$ dengan 30 tanaman lebih besar penurunannya daripada reaktor $A$, B, dan C. Waktu detensi juga salah satu faktor yang menyebabkan penurunan kadar BOD dan COD. Karena semakin lama waktu tinggal limbah, maka semakin besar pula penurunan pada kadar polutan limbah tersebut. Namun dalam penelitian ini belum dapat mengukur kemampuan daya serap tanaman air. Sehingga perlu dilakukan penelitian lebih lanjut untuk mengetahui kemampuan maksimal tanaman air dalam menyerap zat polutan.

Tanaman air mampu menyerap (absorben) zat polutan disekitarnya. Menurut Soemirat (2003), menyatakan bahwa proses absorpsi dapat terjadi 
lewat beberapa bagian tumbuhan, yaitu; akar, terutama zat anorganik dan zat hidrofilik, daun bagi zat yang lipofilik dan stomata untuk masukan gas.

\section{Analisis Penurunan Kadar BOD} dan COD Sesuai dengan Peraturan Gubernur Jawa Timur Nomor 72 Tahun 2013

Pada penelitian ini air limbah kegiatan rumah potong hewan dipaparkan dengan tanaman air jenis Pistia stratiotes dalam reactor. Waktu tinggal air limbah dilakukan dalam 2 hari dengan variasi tanaman 15 tanaman, 20 tanaman, 25 tanaman, dan 30 tanaman. Didapatkan hasil hanya di reaktor $D$ yang berisi 30 tanaman sudah memenuhi baku mutu.

Dalam penelitian ini jumlah tanaman dan fisik tanaman sangat berpengaruh terhadap penurunan kadar BOD dan COD dalam air limbah. Hal ini dibuktikan pada reactor $D$ yang berisi 30 tanaman sanggup menurunkan kadar BOD dan COD hingga memenuhi baku mutu sesuai Peraturan Gubernur Jawa Timur Nomor 72 Tahun 2013.
3. Pengaruh Penanaman Tanaman Air Terhadap Penurunan Kadar BOD dan COD dalam Limbah Cair Berdasarkan hasil analisis menggunakan metode One Way Anova yaitu sig. 0,000 dengan criteria tolak $\mathrm{HO}<0,05$. Menunjukkan bahwa ada pengaruh penanaman tanaman air terhadap penurunan kadar BOD dan COD dalam air limbah dengan variasi tanaman, 15 tanaman, 20 tanaman, 25 tanaman, dan 30 tanaman dengan waktu tinggal masing-masing 2 hari. Hal ini disebabkan karena tanaman air memiliki sifat absorben terhadap zat polutan dilingkungan sekitar. Maka dapat dinyatakan bahwa ada pengaruh penanaman terhadap penurunan kadar BOD dan COD dalam air limbah rumah potong hewan.

Dengan demikian tanaman air Pistia stratiotes melalui kemampuannya sebagai absorben terhadap lingkungan sekitar diharapkan mampu berfungsi menyerap zat polutan di lingkungan perairan sekitarnya, sehingga dampak negative polutan tersebut pada perairan sekitar dapat berkurang. 
KESIMPULAN DAN SARAN

\section{KESIMPULAN}

Berdasarkan

hasil

pembahasan dalam penelitian

ini dapat disimpulkan sebagai

berikut:

1. Kadar penurunan BOD dan COD terbesar pada reaktor $D$ dengan perlakuan 30 tanaman dengan rata-rata BOD sebesar 64,13 ppm dengan persentase $83 \%$ dan penurunan rata-rata COD sebesar 109,38 ppm dengan persentase $\quad 85,53 \%$. Sedangkan penurunan terkecil terjadi pada reaktor $\mathrm{A}$ dengan perlakuan 15 tanaman, penurunan ratarata kadar BOD sebesar 226,45 ppm dengan persentase $\quad 40 \%$ dan penurunan rata-rata COD sebesar 444,67 ppm dengan persentase $41,88 \%$.

2. Pengolahan limbah cair dengan metode fitoremediasi dan reaktor buatan dengan memanfaatkan tanaman air jenis Kayu apu (Pistia stratiotes) dapat menurnkan kadar BOD dan COD dalam limbah cair rumah potong hewan (RPH) sampai kadar maksimal yang diperbolehkan dalam Peraturan Gubernur Jawa Timur No. 72 Tahun 2013.

\section{SARAN}

Berdasarkan pembahasan dalam penelitian ini sehingga disarankan:

1. Perlu diadakan penelitian lebih lanjut untuk penyerapan kadar BOD dan COD pada bagian tanaman air Pistia stratiotes yang mampu melakukan penyerapan lebih besar terhadap BOD dan COD.

2. Perlu dilakukan penelitian lebih lanjut dengan menggunakan dimensi reaktor yang bervariasi.

3. Bagi pengelola perlu diadakan perbaikan pada IPAL Rumah Potong Hewan $(\mathrm{RPH})$ agar limbah tidak melebihi baku mutu 
4. Untuk instansi terkait perlu dilakukan pengawasan yang lebih intens terhadap rumah potong hewan (RPH) agar limbah yang dibuang kedalam badan air memenuhi baku mutu sesuai Peraturan Gubernur Jawa Timur No. 72 Tahun 2013.

\section{DAFTAR PUSTAKA}

Anonymus. 2001. Peraturan Pemerintah Republik Indonesia Nomer 82 Tahun 2001 Tentang Pengelolaan Kualitas Air dan Pengendalian Pencemaran Air. Sekretaris Negara Republik Indonesia. Jakarta

Anonymus. 2013. Peraturan Gubernur Jawa Timur Nomor 72 Tahun 2013 tentang baku mutu air limbah bagi industri dan/atau kegiatan usaha lainnya. Surabaya

Aini, Made Sriasih, Djoko Kisworo. 2017. Studi Pendahuluan Cemaran Air Limbah Rumah Potong Hewan di Kota Mataram. Mataram. Program Studi Ilmu Limgkungan Sekolah Pascasarjana UNDIP. 42-48.

Asmadi, ST, M.Si, Suharno, SKM, M.Kes. 2012. Dasar-Dasar Teknologi Pengolahan Air Limbah. Jatirejo58B RT07/RW21 Sendangadi, Melati, Sleman, Yogyakarta, 55285. Gosyen Publishing. 181.
Dea Ghiovani, Bieby Voijant Tangahu. 2017. Fitoremediasi Air yang Tercemar Limbah Laundry dengan Menggunakan Kayu ари (Pistia stratiotes). Surabaya. Departemen Teknik Lingkungan, Fakultas Teknik Sipil dan Perencanaan. Institut Teknologi Sepuluh Nopember.

Effendi, Hefni. 2003. Telaah Kulitas Air Bagi Pengelolaan Sumber Daya dan Lingkungan Perairan. Yogyakarta. KANISIUS.

Hidayati, Nuril. 2005.Fitoremediasi dan Potensi Tumbuhan Hiperakumulator. Pusat Penelitian Biologi Lembaga Ilmu Pengetahuan Indonesia Vol. 12 No. 1

Kusnoputranto, H. 1985. Air Limbah dan Ekskreta Manusia. Departemen P\&K. Universitas Indonesia. Jakarta.

Manendar R. 2010. Pengolahan Limbah Cair Rumah Potong Hewan (RPH-R) dengan Metode Fotokatalitik TiO2 Pengaruh Waktu Kontak Terhadap Kualitas BOD5, COD, dan pH Efluen. Bogor; Sekolah PAsca Sarjana, Institut Pertanian Bgor

Muhammad Rijal. Studi Morfologi Kayu apu (Pistia stratiotes) dan Kiambang (Salvinia molesta). Ambon. Prodi Pendidikan Biologi. IAIN Ambon

Soemirat S,J. 1994. Kesehatan Lingkungan. Gadjah Mada University Press

Soeparman,H.M., Suparmin. 2001. Pembuangan Tinja dan Limbah Cair: Suatu Pengantar. Jakarta. Penerbit Buku Kedokteran EGC 